\title{
Investigating the Utilization of Ground Palm Kernel Shells for Partial Replacement of Cement in Concrete Using Nondestructive Method
}

\author{
E. A. Armah ${ }^{* 1,2}$, H. A. Koffi ${ }^{1}$, B. J. A. Y. Sogbey ${ }^{3}$, J. K. A. Amuzu ${ }^{1}$ \\ ${ }^{\mathbf{1}}$ Department of Physics, University of Ghana, Legon, Accra, Ghana \\ ${ }^{2}$ Foundation Department, Lancaster University, Ghana, \\ ${ }^{3}$ National Nuclear Research Institute, Ghana Atomic Energy Commission, Accra, Ghana \\ * Corresponding author email: akweteyniiabekah@gmail.com
}

Received: 19 June 2019 / Revised: 11 July 2019 / Accepted: 12 July 2019 / Published: 13 July 2019

\begin{abstract}
ABST RACT
The objective of this research is to investigate the utilization of palm kernel shells in ground form (GPK) for partial replacement of ordinary Portland cement (OPC) in concrete by investigating its optimal strength using nondestructive ultrasonic pulse velocity method for both cubic and cylindrical concrete test specimen. In all a total of 135 cubes and 66 cylinders of concrete were prepared. The dimension of the cubic concrete specimens was $150 \times 150 \times 150 \mathrm{~mm}$ and that of the cylindrical specimens were $110 \mathrm{~mm}$ and $500 \mathrm{~mm}$ diameter and length respectively. The mix design of the GPK shells used as a partial replacement for OPC ranged between $0 \%$ and $50 \%$ by weight of cement using mix ratio of 1:2:4 with water to cement ratio of 0.8 . The concrete specimens were test at curing periods of 7 days, 28 days and 60 days for the cubes and 7 days and 28 days for the cylinders. Based on the results and the analysis done, it was generally observed in all cases that, as the mix ratio is increased, the ultrasonic pulse velocity, modulus of elasticity and the density decreased and as the curing period increased, these values increased across all the mix ratios. The ultrasonic pulse velocity and the density of the specimens shows that concretes containing GPK "fuel" shells has higher values than those containing GPK ordinary shells. Generally, the density, ultrasonic pulse velocity and the modulus of elasticity of concrete containing GPK shells decrease as the replacement percentage increase.
\end{abstract}

Keywords: Concrete, Density, Ground Palm Kernel Shells, Modulus of elasticity, Nondestructive testing, Replacement Percentages, Ultrasonic Pulse Velocity

\section{Introduction}

Concrete, which is made from cement, has been the ultimate material for construction. It is therefore an indisputable fact that concrete is the most indispensable material that is used in infrastructure development throughout the world [1]. It is a material consisting of a hard, chemically inert particulate substance, known as an aggregate (sand and crushed stones) that is bonded together by a binding medium or paste (cement and water) [2]. The use of cement for concrete has long been the basis for development of society for generations. However, cement manufacturing process is technology intensive. The extraction of the raw material causes serious environmental problems by damaging the landscape and most of these raw materials become scarce. Recent events in major urban centers in Africa have shown that, the problem of waste management has become a monster, which has bedeviled most efforts by professionals of city, states and federal authorities. These wastes are due to industrial, agricultural, municipal, and other activities. The increasing need worldwide for sustainable development and preservation of the environment has led to development of new materials using waste materials and by-products of numerous industrial processes [3].

Disposal of solid industrial and agricultural wastes through burning results in environmental degradation. This can be minimized by utilizing the wastes for other purposes. This will help 
overcome waste disposal problems. As a result, the past decade has witnessed many researches that have been carried out for the utilization of such waste in the building industry to partially replace some construction materials especially concrete.

Recent developments have seen some of the components of concrete, partially substituted by the use of agro-based wastes which are economically and environmentally friendly. Typically, among these are rice husk, coconut shell and fibre, guinea corn husk, corn cob, groundnut shells, sugar cane husks, palm oil fuel ash, palm kernel shells and fibre and saw dust. The utilization of waste materials from the palm oil industry in the built industry has seen received much attention mostly as aggregates by using the bunch, the husk, the shells or the fibre. The studies of the effect by the researchers on the use of the ground palm kernel (GPK) shells as partial replacement of cement in order to determine the effectiveness of their use in concrete is not much investigated. The very few works found investigated mechanical properties such as compressive, tensile and flexural strengths on concrete mostly using destructive methods. Research works of such nature includes the works of Olowe and Adebayo [4], Fadele, and Ata [5], Premalatha et al [6], and Ukpaka and Okochi [7].

As part of efforts to make efficient use of GPK shells, this study was conducted to investigate the influences and potential of the partial replacement of cement by GPK shells on the density and strength of concrete as well as to assess the suitability of GPK shells concrete as a structural material using nondestructive testing (NDT) method. So far, no research on GPK shells using NDT method have been reported. Therefore, in this research, ultrasonic pulse velocity (UPV) of NDT method is chosen since this method allows the density, modulus of elasticity and homogeneity of the material to be monitored and provide information about the strength and the existence of internal flaws and defects. It also decreases the cost of the product by reducing scrap and conserving materials, labour and energy [8].

\section{Materials and Methods}

\subsection{Materials}

The materials employed in this study are the following: cement, aggregates, ground palm kernel shells. The cement used was the locally made Diamond Brand Portland limestone cement from Aflao in the Volta region. In this work an expanded coarse aggregate with irregular shape and wide variety of sizes were used. This was due to unavailability of regular and close size aggregates on the market at the time the aggregates were needed for the work. The maximum size was found to be $64 \mathrm{~mm}$ and the minimum size was $9 \mathrm{~mm}$. The fine aggregate used was taken from a sand winning site at Kasoa in the Central region. The palm kernel shells were collected from a palm kernel mill located at Agbogba near Madina, a suburb of Accra in the Greater Accra region of Ghana. They were washed and dried at ambient temperature of an average of $30^{\circ} \mathrm{C}$ for one week. Some of the shells were subjected to incomplete combustion using the methodology for the production of charcoal: they were covered with leaves and soil, set alight and allowed to smoulder for about 3 days. As a result of this process, the shells turned black, lightweight and brittle. These shells are referred to, in this work, as "fuel shells" and the shells not subjected to this process of incomplete combustion are the ordinary shells. The "fuel shells" and the ordinary shells were ground to fine powder in a grinding mill. The water used was obtained from the source that is available for everyday use in houses (i.e., "tap water).

\subsection{Specimen Preparation}

In the preparation of the concrete specimens the masses of aggregates (fine and coarse) and water were kept constant while those of Portland cement and ground palm kernel shells were varied. The mixing ratio used was 1: $2: 4$ (cement: sand: stone, by weight). The weight of the aggregates (fine and coarse) was $2.67 \mathrm{~kg}$ and 5.34 $\mathrm{kg}$ for the cubic and $4.0 \mathrm{~kg}$ and $8.0 \mathrm{~kg}$ for the cylindrical. The ground palm kernel shells replacement percentages were $0 \%, 20 \%, 30 \%$, $40 \%, 50 \%$ and $60 \%$ with the water-tocementitious ratio kept at 0.8 . The various 
Armah et al., J. Mod. Mater.; Vol. 6, Issue 1, pp: 1-12, 2019

components (sand, stone and cement and/or ground palm kernel shells) were thoroughly mixed on a platform. Water was then measured and poured on the dry mixture. The concrete mix was turned over again and again until a homogeneous mix was obtained. The concrete mix was placed in moulds and compacted. Additional compaction was achieved for the cubic moulds by means of a vibrating compactor. The required surface appearance of the specimens was achieved by leveling and smoothing to the level of the mould. In all a total of 135 cubes and 66 cylinders of concrete were prepared in accordance with BS 1881: Part 127 [9]. The dimension of the cubic concrete specimens was $150 \times 150 \times 150 \mathrm{~mm}$ and that of the cylindrical specimens were $110 \mathrm{~mm}$ and 500 $\mathrm{mm}$ diameter and length respectively. The curing periods were 7 days, 28 days and 60 days for the cubes and 7 days and 28 days for the cylinders. The mix design for the test specimens are as shown in Table 1.

\subsection{Test Procedure}

The densities of the concrete specimen were carried in accordance with test standards ASTM C642-09 [10] for the cubes and ISO 4013 [11] for the cylinders. For determination of the ultrasonic pulse velocity, the Portable Ultrasonic Nondestructive Digital Indicating Tester (PUNDIT) was used. To conduct the test, the surfaces of all the specimens were cleaned using a clean dry cloth and rough surfaces were scraped in order to make them smooth and the faces of the transducers were smeared slightly with grease and pressed against the opposite sides of the concrete specimen in accordance with ASTM C597 [12].

\section{Results and Discussion}

\subsection{Density Test}

The data obtained from the density test of the cubic and cylindrical concrete specimens at various GPK shells replacement percentages are shown in Tables 2 and 3 respectively.

Table 1: Concrete Test Specimen Mix Design

\begin{tabular}{|l|c|c|c|c|c|c|c|}
\hline GPK Shells Replacement Ratio $(\%)$ & $\mathbf{0 \%}$ & $\mathbf{2 0 \%}$ & $\mathbf{3 0 \%}$ & $\mathbf{4 0 \%}$ & $\mathbf{5 0 \%}$ & $\mathbf{6 0 \%}$ \\
\hline Cubic Specimen & 0.00 & 0.27 & 0.40 & 0.53 & 0.67 & 0.80 \\
\hline Weight of GPK Shells (kg) & 1.33 & 1.07 & 0.93 & 0.80 & 0.67 & 0.53 \\
\hline Weight of Cement (kg) & 1.33 & 1.34 & 1.33 & 1.33 & 1.34 & 1.33 \\
\hline Total Weight of Material (kg) & 0.00 & 0.40 & 0.60 & 0.80 & 1.00 & 1.20 \\
\hline Cylindrical Specimen & 2.00 & 1.60 & 1.40 & 1.20 & 1.00 & 0.80 \\
\hline Weight of GPK Shells (kg) & 2.00 & 2.00 & 2.00 & 2.00 & 2.00 & 2.00 \\
\hline Weight of Cement (kg)
\end{tabular}

Table 2: Density of Cubic Concrete Specimen at Various Curing Days

\begin{tabular}{|c|c|c|c|c|c|c|}
\hline \multirow{3}{*}{$\begin{array}{l}\text { Replacement } \\
\text { Percentages }\end{array}$} & \multicolumn{6}{|c|}{ Density $\left(\mathbf{k g} / \mathbf{m}^{3}\right)$} \\
\hline & \multicolumn{2}{|c|}{7 days } & \multicolumn{2}{|c|}{28 days } & \multicolumn{2}{|c|}{60 days } \\
\hline & $\begin{array}{c}\text { Ordinary } \\
\text { Shells }\end{array}$ & $\begin{array}{c}\text { Fuel } \\
\text { Shells }\end{array}$ & $\begin{array}{c}\text { Ordinary } \\
\text { Shells }\end{array}$ & $\begin{array}{c}\text { Fuel } \\
\text { Shells }\end{array}$ & $\begin{array}{c}\text { Ordinary } \\
\text { Shells }\end{array}$ & $\begin{array}{c}\text { Fuel } \\
\text { Shells }\end{array}$ \\
\hline $0 \%$ & 2354.57 & 2354.57 & 2443.46 & 2443.46 & 2454.32 & 2454.32 \\
\hline $20 \%$ & 2281.48 & 2307.65 & 2342.72 & 2353.09 & 2358.02 & 2374.81 \\
\hline $30 \%$ & 2231.11 & 2233.09 & 2255.80 & 2270.12 & 2267.16 & 2285.43 \\
\hline $40 \%$ & 2198.52 & 2227.16 & 2217.78 & 2248.89 & 2227.65 & 2262.72 \\
\hline $50 \%$ & 2160.00 & 2221.73 & 2178.77 & 2230.12 & 2189.14 & 2239.51 \\
\hline $60 \%$ & 2140.25 & 2189.14 & 2157.04 & 2202.47 & 2164.44 & 2205.43 \\
\hline
\end{tabular}


Table 3: Density of Cylindrical Concrete Specimen at Various Curing Days

\begin{tabular}{|c|c|c|c|c|}
\hline \multirow{2}{*}{$\begin{array}{c}\text { Replacement } \\
\text { Percentages }\end{array}$} & \multicolumn{3}{|c|}{ Density $\left(\mathbf{k g} / \mathbf{m}^{\mathbf{3}}\right)$} \\
\cline { 2 - 5 } & Ordinary Shells & Fuel Shells & Ordinary Shells & Fuel Shells \\
\cline { 2 - 5 } & 2327.67 & 2327.67 & 2391.85 & 2391.85 \\
\hline $0 \%$ & 2249.46 & 2270.15 & 2291.54 & 2312.23 \\
\hline $20 \%$ & 2217.19 & 2246.30 & 2259.28 & 2288.39 \\
\hline $30 \%$ & 2198.60 & 2221.05 & 2228.06 & 2250.51 \\
\hline $40 \%$ & 2140.74 & 2162.83 & 2158.97 & 2194.75 \\
\hline $50 \%$ & 2072.00 & 2107.07 & 2099.35 & 2138.63 \\
\hline $60 \%$ & & & & \\
\hline
\end{tabular}

The effect of replacement of GPK shells on density of the specimens are graphically represented in figures 1 to 4 . Figure 1 and 2 shows the effects of replacement of GPK ordinary shells and GPK "fuel" shells of the cubic and figure 3 and 4 the effects of the cylindrical concrete specimens respectively. The result shows that the density of concrete samples decreased with increasing percentage of GPK shells and increased with curing age (i.e. the more the ash contents in the concrete, the lower the density) for all replacement mix ratios investigated.

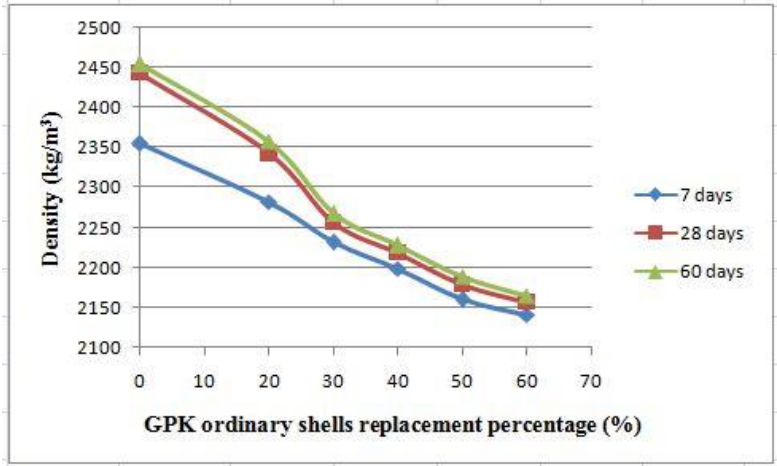

Figure 1: Density of cubic specimen containing GPK ordinary shells at various percentages

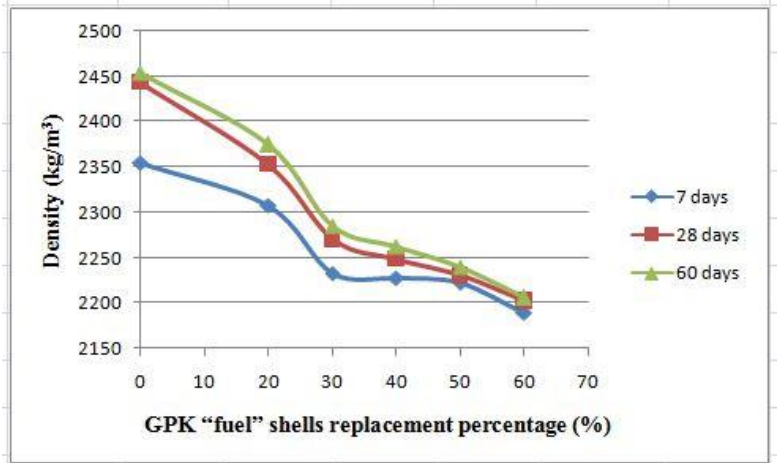

Figure 2: Density of cubic specimen containing GPK "fuel” shells at various percentages
For the cubic concrete specimens containing GPK ordinary shells (figure 1), when cured at 7 days, the test result of the density of concrete ranges from $2140.25-2281.48 \mathrm{~kg} / \mathrm{m}^{3}$ as against $2354.57 \mathrm{~kg} / \mathrm{m}^{3}$ for the control. The density of the $20 \%, 30 \%, 40 \%, 50 \%$ and $60 \%$ replacement are $96.90 \%, 94.76 \%, 93.37 \%, 91.74 \%$ and $90.90 \%$ that of the control at 7 days curing respectively. The effect of GPK ordinary shells on density was slightly less compare with the control samples.

The 28-days curing density obtained were higher than the 7-days density. The result ranges from 2157.04 - $2342.72 \mathrm{~kg} / \mathrm{m}^{3}$ as against 2443.46 $\mathrm{kg} / \mathrm{m}^{3}$ for the control. The density of the respective replacement ratios are $95.877 \%$, $92.32 \%, 90.76 \%, 89.18 \%$ and $88.28 \%$ that of the control. Similarly, the 60-days curing density obtained were higher than the 28-days density. The result ranges from $2164.44-2358.02 \mathrm{~kg} / \mathrm{m}^{3}$ as against $2454.32 \mathrm{~kg} / \mathrm{m}^{3}$ for the control and the density of the replacement ratios of $20 \%, 30 \%$, $40 \%, 50 \%$ and $60 \%$ are $96.08 \%, 92.37 \%, 90.76 \%$, $89.20 \%$ and $88.19 \%$ that of the control. The density for the highest replacement GPK ordinary shells of $60 \%$ was reduced by less than $10 \%, 11.7 \%$ and $11.8 \%$ for the 7 days, 28 -days and 60-days respectively when compare with value of the control concrete.

For the cubic concrete specimens containing GPK "fuel" shells (figure 2), similar trend was observed. The 60-days curing density obtained were higher than the 28-days density and the 28days curing density higher than the 7-days density. When cured at 7 days, the result of the density of concrete ranges from 2189.14 $2307.65 \mathrm{~kg} / \mathrm{m}^{3}$ as against $2354.57 \mathrm{~kg} / \mathrm{m}^{3}$ and the 
Armah et al., J. Mod. Mater.; Vol. 6, Issue 1, pp: 1-12, 2019

density of all the various replacement ratios are $98.01 \%, 94.84 \%, 94.59 \%, 94.36 \%$ and $92.97 \%$ that of the control. The 28-days curing density obtained ranges from $2202.47-2353.09 \mathrm{~kg} / \mathrm{m}^{3}$ as against $2443.46 \mathrm{~kg} / \mathrm{m}^{3}$ for the control. The density of all the various replacement ratios are $96.30 \%, 92.91 \%, 92.04 \%, 91.27 \%$ and $90.14 \%$ that of the control. At the 60-days curing, the result ranges from $2205.43-2374.81 \mathrm{~kg} / \mathrm{m}^{3}$ as against $2454.32 \mathrm{~kg} / \mathrm{m}^{3}$ for the control and the density of the replacement ratios are $96.76 \%$, $93.12 \%, 92.19 \%, 91.25 \%$ and $89.86 \%$ that of the control. The effect of GPK "fuel" shells for the highest replacement ratio on density was found to reduce by at most $7.0 \%, 9.86 \%$ and $10.1 \%$ for the 7-days, 28-days and 60-days respectively when compare with value of the control concrete. For the cylindrical concrete, there was also a decrease in density between the control and the rest of the mix ratios for both the GPK ordinary shells (figure 3) and the GPK "fuel" shells concretes cured at 7 and 28-days (figure 4).

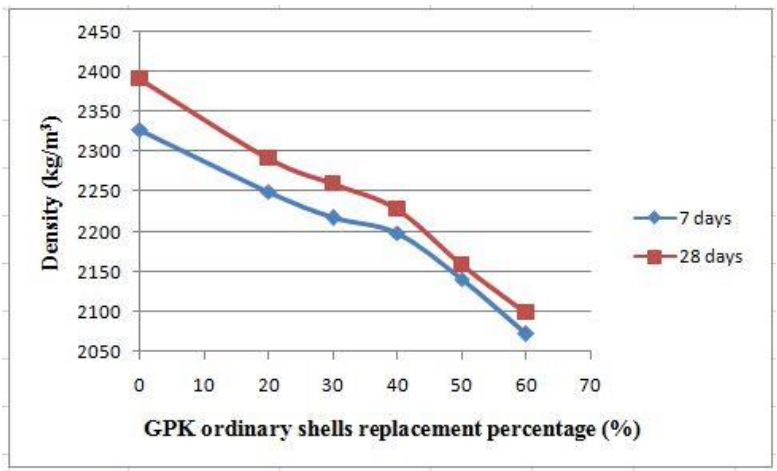

Figure 3: Density of cylindrical specimen containing GPK ordinary shells at various percentages

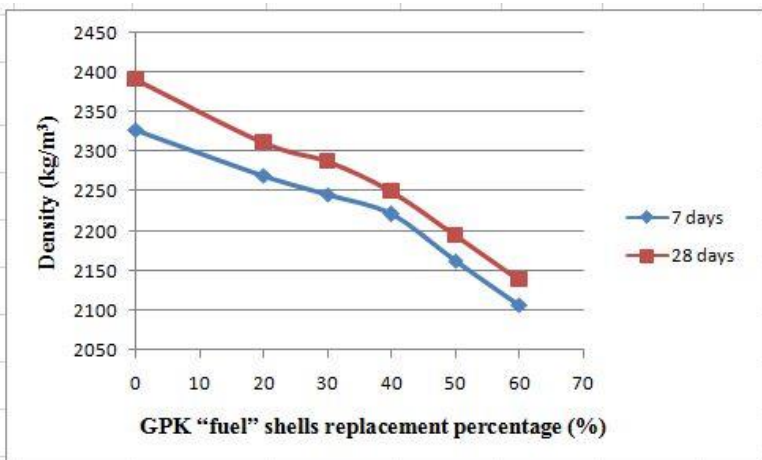

Figure 4: Density of cylindrical specimen containing GPK "fuel" shells at various percentages
When cured at 7 days, the test result of the density of the GPK ordinary shells cylindrical concrete (figure 3), ranges from 2072.00 $2249.46 \mathrm{~kg} / \mathrm{m}^{3}$ as against $2327.67 \mathrm{~kg} / \mathrm{m}^{3}$ for the control. The density of the $20 \%, 30 \%, 40 \%, 50 \%$ and $60 \%$ replacement are $96.64 \%, 95.25 \%$, $94.45 \%, 91.97 \%$ and $89.02 \%$ that of the control respectively. The 28 -days curing density obtained ranges from $2099.35-2291.54 \mathrm{~kg} / \mathrm{m}^{3}$ as against $2391.85 \mathrm{~kg} / \mathrm{m}^{3}$ for the control. The density of all the various replacement ratios are $95.81 \%$, $94.46 \%, 93.15 \%, 90.26 \%$ and $87.77 \%$ that of the control.

For the cylindrical concrete specimens containing GPK "fuel" shells (figure 4), similar trend was observed. The 28-days curing density obtained were higher than the 7-days density. When cured at 7 days, the result of the density of concrete ranges from $2107.07-2270.15 \mathrm{~kg} / \mathrm{m}^{3}$ as against $2327.67 \mathrm{~kg} / \mathrm{m}^{3}$ and the density of all the various replacement ratios are $97.53 \%, 96.50 \%, 95.42 \%$, $92.92 \%$ and $90.52 \%$ that of the control. The 28 days curing density obtained ranges from 2138.63 - $2312.23 \mathrm{~kg} / \mathrm{m}^{3}$ as against $2391.85 \mathrm{~kg} / \mathrm{m}^{3}$ for the control. The density of all the various replacement ratios are 96.67\%, 95.67\%, 94.09\%, $91.76 \%$ and $89.41 \%$ that of the control.

The effect of GPK ordinary shells for the highest replacement ratio of the cylindrical specimen on density was found to reduce by at most $10.98 \%$ and $12.23 \%$ and that of the GPK "fuel shells" was $9.48 \%$ and $10.59 \%$ for the 7 -days and 28 days respectively when compared with value of the control concrete.

Replacement of cement by equal mass of GPK shells leads to a decrease in the density of both the cubic and the cylindrical concrete specimens with reference to the control. However, as curing period is increased, the density of the specimens increased. The decrease in density due to partial replacement of OPC is attributed to the higher density of cement than the GPK shells. The increase in density as curing period increase is also attributed to the filling of voids or pores in the concrete specimen. The density of the cubic specimen is higher than that of the cylindrical for concrete specimens containing both ordinary shells and "fuel" shells. This is because additional compaction was achieved for the cubic moulds 
Investigating the Utilization of Ground Palm Kernel Shells for Partial Replacement of Cement in Concrete Using Nondestructive Method

by means of a vibrating compactor which was not possible with the cylindrical moulds. Additionally, the density of the GPK "fuel" shells concrete specimens was found to be higher than that of GPK ordinary shells specimen since the true density of GPK "fuel" shells in powdered form is denser than the GPK ordinary shells. Conventional concrete, normally used in pavements, buildings, and other structures, has a density in the range of 1750 to $2400 \mathrm{~kg} / \mathrm{m}^{3}$ at 28 days curing period [13] [14]. The concrete specimens of the cubic and the cylindrical containing both GPK ordinary shells and "fuel" shells at all the curing ages fall within this range and are classified as lightweight concrete according to Newman and Choo [15]. This implies that all the concrete specimens satisfy the minimum density requirement for structural purposes as is also reported by Olutoge [16].

\subsection{Ultrasonic Pulse Velocity Test}

The data obtained from the ultrasonic pulse velocity test of the cubic and cylindrical concrete specimens at various GPK shells replacement percentages are shown in Tables 4 and 5 respectively.

Table 4: Ultrasonic Pulse Velocity of Cubic Concrete Specimen at Various Curing Days

\begin{tabular}{|c|c|c|c|c|c|c|}
\hline \multirow{2}{*}{$\begin{array}{c}\text { Replacement } \\
\text { Percentages }\end{array}$} & \multicolumn{2}{|c|}{ Ultrasonic Pulse Velocity (m/s) } \\
\cline { 2 - 7 } & $\mathbf{7}$ days & \multicolumn{2}{c|}{$\mathbf{2 8}$ days } & \multicolumn{2}{c|}{$\mathbf{6 0 \text { days }}$} \\
\cline { 2 - 7 } & $\begin{array}{c}\text { Ordinary } \\
\text { Shells }\end{array}$ & $\begin{array}{c}\text { Fuel } \\
\text { Shells }\end{array}$ & $\begin{array}{c}\text { Ordinary } \\
\text { Shells }\end{array}$ & $\begin{array}{c}\text { Fuel } \\
\text { Shells }\end{array}$ & $\begin{array}{c}\text { Ordinary } \\
\text { Shells }\end{array}$ & $\begin{array}{c}\text { Fuel } \\
\text { Shells }\end{array}$ \\
\hline \multirow{2}{*}{$0 \%$} & 3843.17 & 3843.17 & 4335.67 & 4371.00 & 4494.67 & 4494.67 \\
\hline \multirow{2}{*}{$20 \%$} & 3120.33 & 3173.33 & 3816.67 & 4072.33 & 3976.00 & 4166.33 \\
\hline $40 \%$ & 3082.00 & 3107.67 & 3574.33 & 3694.33 & 3702.67 & 3823.00 \\
\hline $50 \%$ & 2656.67 & 2882.67 & 3150.67 & 3335.67 & 3340.67 & 3531.67 \\
\hline & 2202.33 & 2616.83 & 2712.67 & 3162.33 & 3104.00 & 3272.33 \\
\hline & 1886.00 & 2393.83 & 2391.00 & 2839.67 & 2671.33 & 2925.33 \\
\hline
\end{tabular}

Table 5: Ultrasonic Pulse Velocity of Cylindrical Concrete Specimen at Various Curing Days

\begin{tabular}{|c|c|c|c|c|}
\hline \multirow{2}{*}{$\begin{array}{c}\text { Replacement } \\
\text { Percentages }\end{array}$} & \multicolumn{2}{|c|}{ Ultrasonic Pulse Velocity $(\mathbf{m} / \mathbf{s})$} \\
\cline { 2 - 5 } & 7 days & \multicolumn{2}{c|}{ 28 days } \\
\cline { 2 - 5 } & Ordinary Shells & Fuel Shells & Ordinary Shells & Fuel Shells \\
\hline $0 \%$ & 3223.67 & 3223.67 & 3976.33 & 3976.33 \\
\hline $20 \%$ & 2843.00 & 3005.67 & 3516.00 & 3674.33 \\
\hline $30 \%$ & 2592.33 & 2715.67 & 3321.33 & 3438.33 \\
\hline $40 \%$ & 2380.00 & 2502.67 & 2834.33 & 3255.00 \\
\hline $50 \%$ & 2014.33 & 2293.00 & 2610.00 & 2778.00 \\
\hline $60 \%$ & 1400.33 & 1821.00 & 2279.67 & 2431.00 \\
\hline
\end{tabular}


Armah et al., J. Mod. Mater.; Vol. 6, Issue 1, pp: 1-12, 2019

The effect of replacement of GPK shells on ultrasonic pulse velocity of the specimens are graphically represented in figures 5 to 8 . Figure 5 and 6 shows the effects of replacement of GPK ordinary shells and GPK "fuel" shells of the cubic specimens and figures 7 and 8 that of the cylindrical respectively. The result shows that the ultrasonic pulse velocity of concrete samples decreased with increasing percentage of GPK shells. The decrease becomes more significant when the replacement percentages are increased. However, prolonging the curing time obviously increases the ultrasonic pulse velocity of concrete slightly.

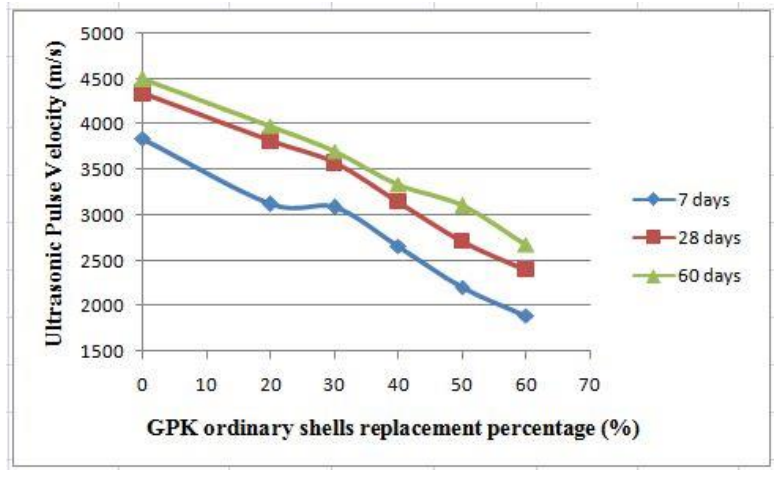

Figure 5: Ultrasonic pulse velocity of cubic specimen containing GPK ordinary shells at various percentages

For the cubic concrete specimens containing GPK ordinary shells (figure 5), when cured at 7 days, the test result of the ultrasonic pulse velocity of concrete ranges from 1886.00 $3120.33 \mathrm{~m} / \mathrm{s}$ as against $3843.17 \mathrm{~m} / \mathrm{s}$ for the control. The ultrasonic pulse velocity of these concretes decreases to $81.19 \%, 80.19 \%, 69.13 \%$, $57.31 \%$ and $49.07 \%$ at various replacement percentages with reference to the control mix. At 28 days of curing, the ultrasonic pulse velocity for the control increased to $4335.67 \mathrm{~m} / \mathrm{s}$. This shows an increment of $12.8 \%$. The test result ranges from 2391.00 - $3816.67 \mathrm{~m} / \mathrm{s}$ for the various replacement percentages respectively. The decrease in the ultrasonic pulse velocity was $88.03 \%, 82.44 \%, 72.67 \%, 62.57 \%$ and $55.15 \%$ that of the control for the various replacement percentages. Between the controls of 28-day and 60 -day curing periods, there was a difference of $159 \mathrm{~m} / \mathrm{s}$ in the pulse velocity which corresponds to only $3.67 \%$. The test result ranges from
2671.33 - $3976.00 \mathrm{~m} / \mathrm{s}$ for the various replacement percentages respectively as against $4494.67 \mathrm{~m} / \mathrm{s}$ for the control. The ultrasonic pulse velocity decreases to $88.46 \%, 82.38 \%, 74.33 \%$, $69.06 \%$ and $59.43 \%$ that of the control for the various replacement percentages.

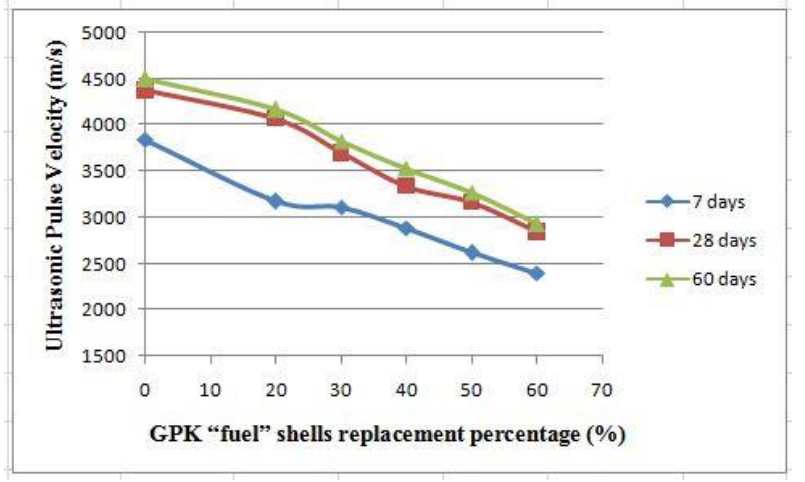

Figure 6: Ultrasonic pulse velocity of cubic specimen containing GPK "fuel" shells at various percentages

Considering the cubic concrete specimens containing GPK "fuel" shells (figure 6), the trend is the same as that of the GPK ordinary shells concrete specimens. The ultrasonic pulse velocity result ranges from $2393.83-3173.33 \mathrm{~m} / \mathrm{s}$ for the various replacement percentages. The ultrasonic pulse velocity values correspond to $82.57 \%$, $80.86 \%, 75.01 \%, 68.09 \%$ and $62.29 \%$ of the control mix. At 28 days, the result ranges from $2839.67-4072.33 \mathrm{~m} / \mathrm{s}$ and the decrease in the ultrasonic pulse velocity was $93.93 \%, 85.21 \%$, $76.94 \%, 72.94 \%$ and $65.50 \%$ that of the control for the various replacement percentages respectively. At 60-days, the result ranges from 2925.33 - $4166.33 \mathrm{~m} / \mathrm{s}$ and the decrease in the ultrasonic pulse velocity was $92.69 \%, 85.06 \%$, $78.57 \%, 72.80 \%$ and $65.08 \%$ that of the control for the various replacement percentages respectively.

For the cylindrical concrete specimens, the graphical representation of the ultrasonic pulse velocity results for the GPK ordinary shells and GPK "fuel" shells can be observed from figure 7 and 8 respectively. The ultrasonic pulse velocity for the GPK ordinary shells (figure 7) at 7 days curing period was found to be $3223.67 \mathrm{~m} / \mathrm{s}$ for the control and vary from $1400.33 \mathrm{~m} / \mathrm{s}$ to $2843.00 \mathrm{~m} / \mathrm{s}$ by varying the replacement ratio of the GPK ordinary shells. The ultrasonic pulse 
velocity of these concretes was found to decrease to $88.19 \%, 80.42 \%, 73.83 \%, 62.49 \%$ and $43.44 \%$ at various replacement percentages with reference to the control mix. At 28-day curing period, the ultrasonic pulse velocity for the control was increased from $3223.67 \mathrm{~m} / \mathrm{s}$ to $3976.33 \mathrm{~m} / \mathrm{s}$. The ultrasonic pulse velocity values are observed to vary from $2431.00 \mathrm{~m} / \mathrm{s}$ to $3674.33 \mathrm{~m} / \mathrm{s}$ when the GPK ordinary shells replacement percentages were varied. The decrease corresponds to $92.4 \%, 86.47 \%, 81.86 \%$, $69.86 \%$ and $61.14 \%$ of the control for the various replacement percentages.

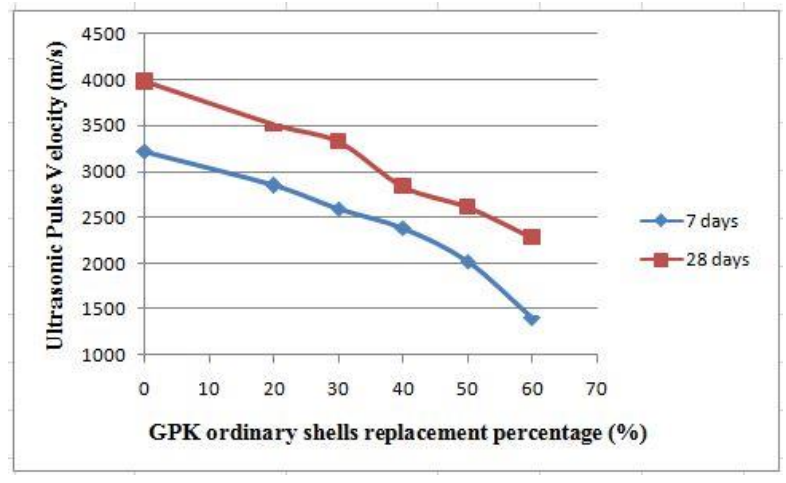

Figure 7: Ultrasonic pulse velocity of cylindrical specimen containing GPK ordinary shells at various percentages

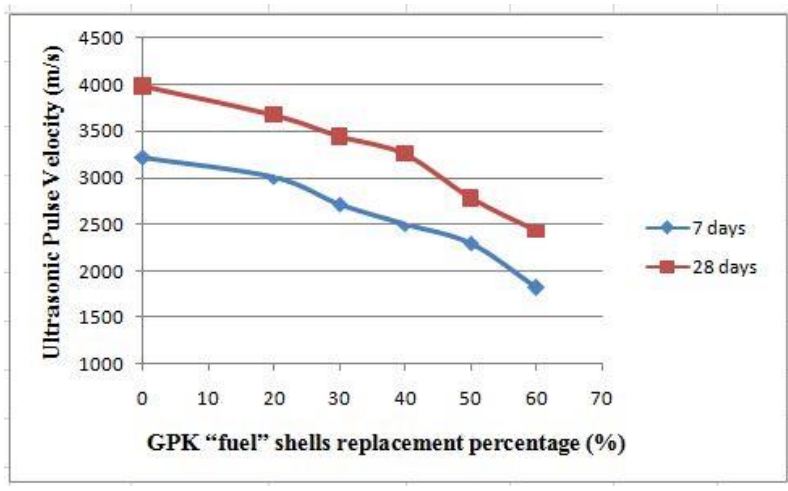

Figure 8: Ultrasonic pulse velocity of cylindrical specimen containing GPK "fuel" shells at various percentages

For the cylindrical concrete specimens containing GPK "fuel" shells (figure 8) cured at 7 days, the ultrasonic pulse velocity result ranges from 1821 $\mathrm{m} / \mathrm{s}$ to $3005.67 \mathrm{~m} / \mathrm{s}$ as against $3223.67 \mathrm{~m} / \mathrm{s}$ for the control. When the GPK "fuel" shells were varied, the decrease in ultrasonic pulse velocity corresponds to $93.24 \%, 84.24 \%, 77.63 \%, 71.13 \%$ and $56.48 \%$ of the control for the various replacement percentages. At 28-day curing period, the ultrasonic pulse velocity values vary from $3223.67 \mathrm{~m} / \mathrm{s}$ to $3976.33 \mathrm{~m} / \mathrm{s}$ when the GPK ordinary shells replacement percentages were varied. The decrease corresponds to $92.4 \%$, $86.47 \%, 81.86 \%, 69.86 \%$ and $61.14 \%$ of the control for the various replacement percentages. Similarly, replacement of cement by equal mass of GPK shells leads to a decrease in the ultrasonic pulse velocity of both the cubic and the cylindrical concrete specimens with reference to the control. However, as curing period is increased, the ultrasonic pulse velocity of the specimens increased. The ultrasonic pulse velocity of the cubic specimen is higher than that of the cylindrical for concrete specimens containing both ordinary shells and "fuel" shells. This is because additional compaction was achieved for the cubic moulds by means of a vibrating compactor which was not possible with the cylindrical moulds. The additional compaction in the cubic moulds possibly reduces voids in the concrete specimens. Also, the ultrasonic pulse velocity of the GPK "fuel" shells concrete specimens was found to be higher than that of GPK ordinary shells specimen since the true density of GPK "fuel" shells in powdered form is denser and so less porous than the GPK ordinary shells. The decrease in velocity of the concrete specimens with GPK shells prepared reveals that, porosity and air content increases with the decrease in cement content. Similarly, the degree of compaction affects the volume of voids in concrete comparing the cubic and the cylindrical specimens. Additionally, because the density of GPK shells is lower than that of cement, concrete made with GPK shells has lower than that of cement. For the same reason, concrete made with GPK shells has a higher porosity and absorption and so also is the concrete made with GPK ordinary shells more porous than GPK "fuel" shells.

For quality grading of concrete, the standard for classification is such that, for ultrasonic pulse velocity greater than $4.5 \mathrm{~km} / \mathrm{s}$, the concrete is excellent. Other classifications are, between 3.5 $\mathrm{km} / \mathrm{s}$ to $4.5 \mathrm{~km} / \mathrm{s}$, good; between $3.0 \mathrm{~km} / \mathrm{s}$ to 3.5 $\mathrm{km} / \mathrm{s}$, satisfactory; between $2.0 \mathrm{~km} / \mathrm{s}$ and 3.0 $\mathrm{km} / \mathrm{s}$, doubtful and less than $2.0 \mathrm{~km} / \mathrm{s}$, poor [17]. Classifying the concretes at 28 days curing age, 
Armah et al., J. Mod. Mater.; Vol. 6, Issue 1, pp: 1-12, 2019

the cubic specimens with GPK ordinary shells replacement percentage of $20 \%$ is classified as good, $30 \%$ and $40 \%$ classified as satisfactory, and $50 \%$ and $60 \%$ is classified as doubtful or poor. For the concrete specimens with GPK "fuel" shells, $20 \%$ and $30 \%$ is classified as good, $40 \%$ and $50 \%$ classified as satisfactory, and only the $60 \%$ as doubtful. For the cylindrical specimens, the $20 \%$ is classified as good, $30 \%$ GPK ordinary shells and 30\% and 40\% GPK "fuel" shells classified as satisfactory, and the rest classified as doubtful. All specimens degraded from "good", to "doubtful", but non fall within the "poor" category in terms of quality.

\subsection{Modulus of Elasticity Test}

Figure 9, 10, 11 and 12 shows the representative results of the modulus of elasticity. The result obtained from the cubic concrete (Table 6) has been graphically represented in figures 9 and 10 for GPK ordinary shells and GPK "fuel" shells respectively.

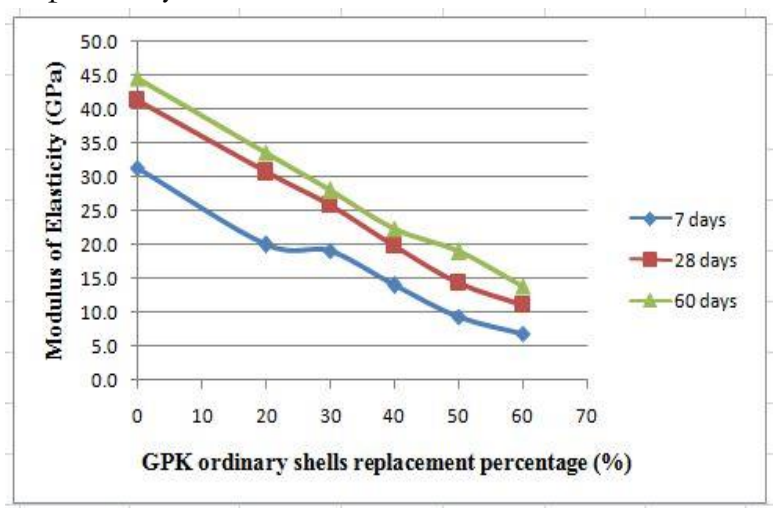

Figure 9: Modulus of elasticity of cubic specimen containing GPK ordinary shells at various percentages

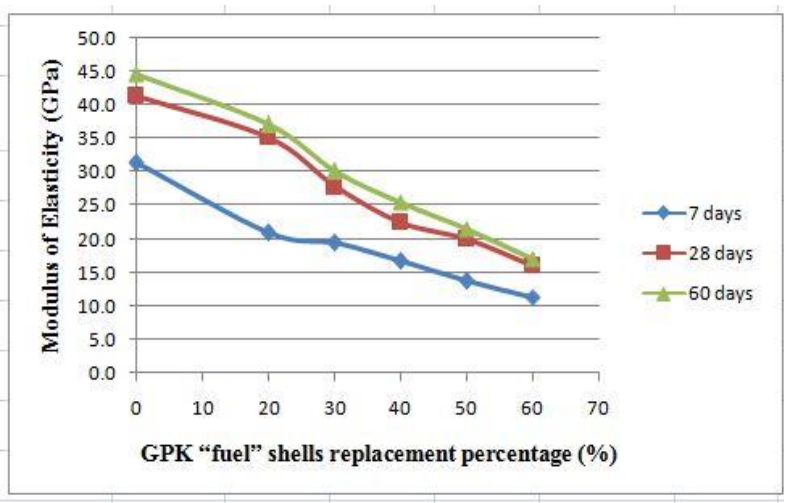

Figure 10: Modulus of elasticity of cubic specimen containing GPK "fuel" shells at various

percentages
The modulus of elasticity for the GPK ordinary shells (figure 9) at 7 days curing period was found to be $31.30 \mathrm{GPa}$ for the control and vary from 6.85 GPa to 20.0 GPa by varying the replacement ratio of the GPK ordinary shells. The modulus of elasticity of these concretes was found to decrease to $63.9 \%, 60.93 \%, 44.63 \%, 30.13 \%$ and $21.89 \%$ at various replacement percentages with reference to the control mix. At 28-day curing period, the modulus of elasticity for the control increased to $41.35 \mathrm{GPa}$. This shows an increment of approximately $32.11 \%$. At this curing age the modulus of elasticity varies from $11.10 \mathrm{GPa}$ to 30.72 GPa when the GPK ordinary shells replacement percentages were varied. The decrease corresponds to $74.29 \%, 62.73 \%$, $47.93 \%, 34.9 \%$ and $26.6 \%$ of the control for the various replacement percentages. As the curing periods increased from 28-day to 60 days, the modulus of elasticity for the control increased to 44.63 GPa with a difference of 3.28 GPa which corresponds to $7.9 \%$. The test result for the various replacement percentages ranges from 13.91 $\mathrm{GPa}$ to $33.56 \mathrm{GPa}$. The percentage decrease in the modulus of elasticity with respect to the control for the various replacement percentages was $75.2 \%, 62.9 \%, 50.15 \%, 42.55 \%$ and $31.17 \%$ respectively.

Considering the cubic concrete specimens containing GPK "fuel" shells (figure 10), the trend is the same as that of the GPK ordinary shells concrete specimens. The modulus of elasticity results for the 7 days curing period ranges from $11.29 \mathrm{GPa}$ to $20.92 \mathrm{GPa}$ for the various replacement percentages. The values correspond to $66.84 \%, 62.01 \%, 53.23 \%$, 43.77\% and $36.07 \%$ of the control mix. At 28 days, the result ranges from $16.00 \mathrm{GPa}$ to $35.12 \mathrm{GPa}$ and the decrease in the modulus of elasticity was $84.93 \%, 67.45 \%, 54.46 \%, 48.54 \%$ and $38.69 \%$ that of the control for the various replacement percentages respectively. At 60-days, the result ranges from $17.00 \mathrm{GPa}$ to $37.10 \mathrm{GPa}$ and the decrease in the modulus of elasticity was $83.13 \%$, $67.38 \%, 56.96 \%, 48.35 \%$ and $38.09 \%$ that of the control for the various replacement percentages respectively. 
Table 6: Modulus of elasticity of Cubic Concrete Specimen at Various Curing Days

\begin{tabular}{|c|c|c|c|c|c|c|}
\hline \multirow{3}{*}{$\begin{array}{l}\text { Replacement } \\
\text { Percentages }\end{array}$} & \multicolumn{6}{|c|}{ Modulus of Elasticity (GPa) } \\
\hline & \multicolumn{2}{|c|}{7 days } & \multicolumn{2}{|c|}{28 days } & \multicolumn{2}{|c|}{60 days } \\
\hline & $\begin{array}{l}\text { Ordinary } \\
\text { Shells }\end{array}$ & $\begin{array}{c}\text { Fuel } \\
\text { Shells }\end{array}$ & $\begin{array}{l}\text { Ordinary } \\
\text { Shells }\end{array}$ & $\begin{array}{l}\text { Fuel } \\
\text { Shells }\end{array}$ & $\begin{array}{c}\text { Ordinary } \\
\text { Shells }\end{array}$ & $\begin{array}{l}\text { Fuel } \\
\text { Shells }\end{array}$ \\
\hline $0 \%$ & 31.30 & 31.30 & 41.35 & 41.35 & 44.63 & 44.63 \\
\hline $20 \%$ & 20.00 & 20.92 & 30.72 & 35.12 & 33.56 & 37.10 \\
\hline $30 \%$ & 19.07 & 19.41 & 25.94 & 27.89 & 27.98 & 30.07 \\
\hline $40 \%$ & 13.97 & 16.66 & 19.82 & 22.52 & 22.38 & 25.42 \\
\hline $50 \%$ & 9.43 & 13.70 & 14.43 & 20.07 & 18.99 & 21.58 \\
\hline $60 \%$ & 6.85 & 11.29 & 11.10 & 16.00 & 13.91 & 17.00 \\
\hline
\end{tabular}

The modulus of elasticity results obtained from the cylindrical specimen's measurement (Table 7) has been graphically represented in figures 11 and 12 for GPK ordinary shells and GPK "fuel" shells respectively.

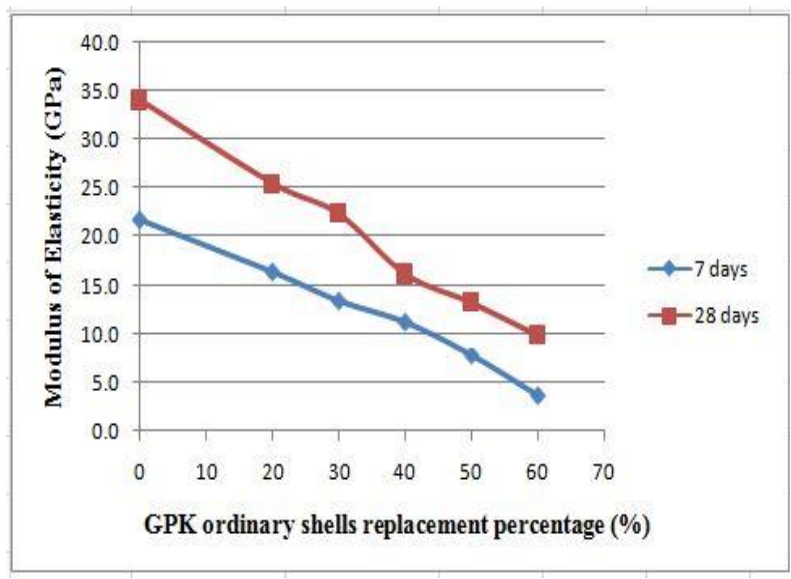

Figure 11: Modulus of elasticity of cylindrical specimen containing GPK ordinary shells at various percentages

The modulus of elasticity of the control specimen for the GPK ordinary shells (figure 11) at 7 days of curing was $18.04 \mathrm{GPa}$. As the mix ratio is increased, the modulus of elasticity decreased and vary from 3.66 GPa to $16.36 \mathrm{GPa}$. The decrease was found to be $75.15 \%, 61.6 \%, 51.49 \%, 35.97 \%$ and $16.81 \%$ at the various replacement percentages with reference to the control mix. At 28-day curing period, the modulus of elasticity for the control was increased to $34.04 \mathrm{GPa}$ and vary from $9.82 \mathrm{GPa}$ to $25.50 \mathrm{GPa}$ when the GPK ordinary shells replacement percentages were varied. The decrease observed as a result of the various replacement percentages corresponds to
$74.91 \%, 65.89 \%, 47.33 \%, 38.92 \%$ and $28.85 \%$ of the control. Considering the cubic concrete specimens containing GPK "fuel" shells (figure 12), the trend is the same as that of the GPK ordinary shells concrete specimens.

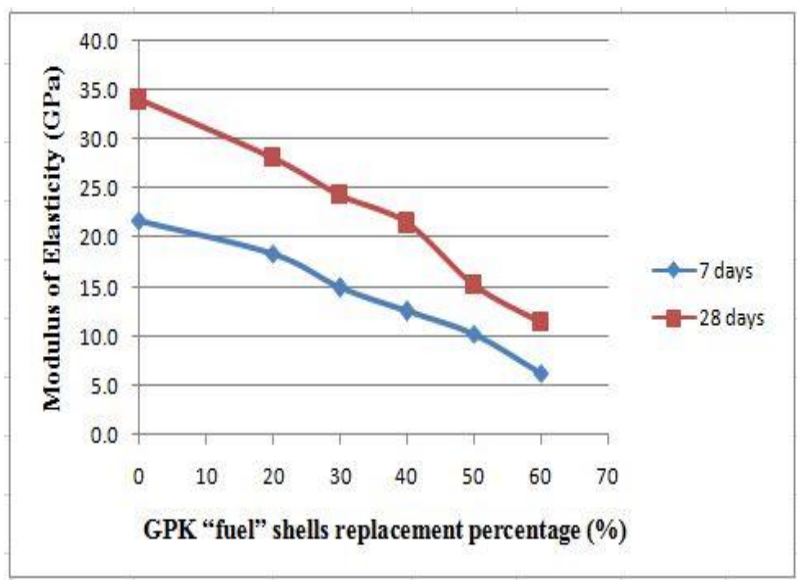

Figure 12: Modulus of elasticity of cylindrical specimen containing GPK "fuel" shells at various percentages

The modulus of elasticity results for the 7 days curing period ranges from $6.30 \mathrm{GPa}$ to $18.46 \mathrm{GPa}$ for the various replacement percentages. The decrease in the modulus of elasticity values as the replacement percentages were varied correspond to $84.8 \%, 68.49 \%, 57.51 \%, 46.99 \%$ and $28.947 \%$ of the control mix. At 28 days, the result ranges from $11.38 \mathrm{GPa}$ to $28.10 \mathrm{GPa}$ and the decrease in the modulus of elasticity was $82.55 \%, 71.53 \%$, $63.04 \%, 44.77 \%$ and $33.43 \%$ that of the control for the various replacement percentages respectively. 
Table 7: Modulus of elasticity of Cylindrical Concrete Specimen at Various Curing Days

\begin{tabular}{|c|c|c|c|c|}
\hline \multirow{2}{*}{$\begin{array}{c}\text { Replacement } \\
\text { Percentages }\end{array}$} & \multicolumn{3}{|c|}{ Modulus of Elasticity (GPa) } \\
\cline { 2 - 5 } & \multicolumn{2}{|c|}{ 7 days } & \multicolumn{2}{c|}{ 28 days } \\
\cline { 2 - 5 } & $\begin{array}{c}\text { Ordinary } \\
\text { Shells }\end{array}$ & $\begin{array}{c}\text { Fuel } \\
\text { Shells }\end{array}$ & $\begin{array}{c}\text { Ordinary } \\
\text { Shells }\end{array}$ & $\begin{array}{c}\text { Fuel } \\
\text { Shells }\end{array}$ \\
\hline $0 \%$ & 21.77 & 21.77 & 34.04 & 34.04 \\
\hline $20 \%$ & 16.36 & 18.46 & 25.50 & 28.10 \\
\hline $30 \%$ & 13.41 & 14.91 & 22.43 & 24.35 \\
\hline $40 \%$ & 11.21 & 12.52 & 16.11 & 21.46 \\
\hline $50 \%$ & 7.83 & 10.23 & 13.25 & 15.24 \\
\hline $60 \%$ & 3.66 & 6.30 & 9.82 & 11.38 \\
\hline
\end{tabular}

Like the density and the ultrasonic pulse velocity, as the curing period increased, the modulus of elasticity increased across all the mix ratios and as curing period is increased, the ultrasonic pulse velocity of the specimens increased. Comparison of the modulus of elasticity of GPK ordinary shells with that of GPK "fuel" shells at all ages and mixed ratios, the "fuel" shells was found to have significantly higher modulus of elasticity. The modulus of elasticity of lightweight concrete generally ranges from 6.89 to $20.68 \mathrm{GPa}$ and that of normal-weight concrete is between 13.79 and $41.37 \mathrm{GPa}$ [18]. Based on the classification of Merritt and Ricketts [18] using the 28 days curing age, all the concrete specimens fall within the lightweight range (6.89 to $20.68 \mathrm{GPa})$. Interestingly, the cubic concrete specimens of the control mix whose density falls within the normal-weight concrete classification, has the modulus of elasticity also falling within the same normal-weight class (41.37 GPa).

\section{Conclusions}

From the results and the analysis done, it was observed that as the mix ratio is increased, the density, ultrasonic pulse velocity and modulus of elasticity decreased and as the curing period increased, these values increased across all the mix ratios. The density, ultrasonic pulse velocity and modulus of elasticity of the "fuel" shells specimen are higher than that of the ordinary shells. Based on the above findings, $30 \%$ of the GPK "fuel" shells and $20 \%$ of GPK ordinary shells could be used for partial replacement of OPC in concrete for pavements, buildings, and other lightweight structural concrete. The use of
GPK shells for partial replacement of OPC of $20 \%$ can decreases the cost of the concrete product by the reduction of cement. It will also reduce environmental pollution due to dumping of such agro-based waste thereby conserving materials, labour and energy.

\section{Declarations}

\subsection{Acknowledgment}

The authors gratefully acknowledged the support of the Civil Engineering Dept. of Ghana Standards Authority, NDT Dept. of Ghana Atomic Energy Commission and Ghana Cement Company (Ghacem) Ltd, for the unrestricted access to their laboratories and resources.

\subsection{Competing Interests}

The authors declared that no conflict of interest exist in this publication

\section{How to Cite this Article}

E. Armah, H. Koffi, B. Sogbey, and J. Amuzu, "Investigating the Utilization of Ground Palm Kernel Shells for Partial Replacement of Cement in Concrete Using Nondestructive Method", J. Mod. Mater., vol. 6, no. 1, pp. 1-12, Jul. 2019. doi: 10.21467/jmm.6.1.1-12

\section{References}

[1] S. Keerthinarayana and R. Srinivasan, "Study on Strength and Durability of Concrete by Partial Replacement of Fine Aggregate Using Crushed Spent Fire Bricks," Directory of Open Access Journals, LVI (LX) (2), pp. 51-64, 2010.

[2] N. S. Martys, "Survey of Concrete Transport Properties and Their Measurement," National Institute of Standards and Technology, Gaithersburg, 1995.

[3] D. Johnston, "AAFA International Product Safety and Sustainability Conference," 29 Corporate Sustainability Programme, American Efird Inc., China, April 2011.

[4] K. O. Olowe and V. B. Adebayo, "Investigation on Palm Kernel Ash as Partial Cement Replacement in High Strength Concrete," SSRG International Journal of Civil Engineering (SSRG-IJCE), vol. 2, no. 4, pp. 45, April 2015.

[5] O. A Fadele and O. Ata, "Compressive Strength of Concrete Containing Palm Kernel Shell Ash," American Journal of Engineering Research (AJER), vol. 5, no. 12, pp. 32-36, 2016.

[6] P. Premalatha, K. R. Vinodh, L. C. Anto and R. Nithiya, "Properties of Palm Ash Concrete," International Journal of Engineering Science Invention, vol. 5, no. 8, pp. 29-32, August 2016.

[7] C. P. Ukpaka and G. I. Okochi, "Production of Cement from Mixture of Palm Kernel and Periwinkle Shell," Indian Journal of Engineering, vol. 15, pp. 166-179, 2018. 
[8] IAEA, "Basic Principles of Non-Destructive Testing (NDT)," Training Guidelines In Non-Destructive Testing Techniques: Manual For Visual Testing At Level 2, VIENNA, IAEA-TCS-54, ISSN 1018-5518, Austria, pp. 1, 2013.

[9] British Standards, "BS 1881: Part 127, Method of verifying the Performance of concrete cube compression Machine using the cube test," Testing Concrete, British Standards Institution, London, 1990

[10] ASTM C642-09, "Standard Test Method for Density, Absorption, and Voids in Hardened Concrete," American Concrete Institute.

[11] ISO 4013-1978(E), Concrete-Determination of flexural strength of test specimen, International Organization for Standardization, Switzerland, August 1978.

[12] ASTM C597-09, "Standard Test Method for Pulse Velocity Through Concrete", American Concrete Institute, 2009

[13] R. Dorf, Engineering Handbook. New York: CRC Press, 1996.

[14] S. H. Kosmatka, B. Karkhoff and W. C. Panarese, Design and Control of Concrete Mixture, $14^{\text {th }}$ ed. Portland Cement Association, Skokie Illinois, USA, 2003.

[15] J. Newman and B. S. Choo, "Elasticity, Shrinkage, Creep And Thermal Movement," Advanced Concrete Technology-Concrete Properties, Elsevier Butterworth Heinemann, Great Britain, pp. 7/2-3, 2003.

[16] F. A. Olutoge, H. A. Quadri, O. S. Olafusi, "Investigation of the Strength Properties of Palm Kernel Shell Ash Concrete," ETASR - Engineering, Technology \& Applied Science Research, vol. 2, no. 6, pp. 315-319, 2012.

[17] V. M. Malhotra and N. J. Carino, "The Ultrasonic Pulse Velocity Method," Handbook on Nondestructive Testing of Concrete, $2^{\text {nd }}$ ed. CRC Press, New York, USA, 2004.

[18] F. S. Merritt and J. T. Ricketts, " Building Materials," Building Design And Construction Handbook, $6^{\text {th }} \mathrm{ed}$, McGraw-Hill Companies, Inc., United States of America, pp. 4.23, 2001.

\section{Publish your research article in AIJR journals-}

$\checkmark \quad$ Online Submission and Tracking

$\checkmark$ Peer-Reviewed

$\checkmark \quad$ Rapid decision

$\checkmark \quad$ Immediate Publication after acceptance

$\checkmark \quad$ Articles freely available online

$\checkmark \quad$ Retain full copyright of your article.

Submit your article at journals.aijr.in

\section{Publish your books with AIJR publisher-}

$\checkmark \quad$ Publish with ISBN and DOI.

$\checkmark \quad$ Publish Thesis/Dissertation as Monograph.

$\checkmark$ Publish Book Monograph.

$\checkmark \quad$ Publish Edited Volume/ Book.

$\checkmark \quad$ Publish Conference Proceedings

$\checkmark \quad$ Retain full copyright of your books.

Submit your manuscript at books.aijr.org 